\title{
Survey of Drug Use in Labour in a Kuwaiti Hospital: A Pilot Study
}

\author{
Ma'asoumah Makhseed $^{\mathrm{a}, \mathrm{b}}$ Moorkath Nandakumaran $^{\mathrm{a}}$ \\ Mohammad Abrar Ahmed ${ }^{a}$ Vijaya Lakshmi ${ }^{b}$ Iman Al Shimalee ${ }^{b}$ \\ Khalida AI Qallaf ${ }^{b}$ \\ aDepartment of Obstetrics and Gynaecology, Faculty of Medicine, Kuwait University, and \\ bMaternity Hospital, Kuwait
}

\section{Key Words}

Drugs · Labour · Pilot study, drug use

\begin{abstract}
Objective: To study the trends of drugs used in labour in Kuwait. Methods: A drug survey of a total of 326 mothers was conducted in the labour room of the Maternity Hospital, Kuwait. Data were collected from the prescription sheets and patient files by four doctors from the labour room based on a 4-day duty rotation schedule. Results: Percentages of the prescribed drugs were: analgesics 59.5, tranquilizers 25.5, uterotonics 7.4 , antibiotics 5.5, anticonvulsants 0.9 , antihypertensives 1.5, and $\mathrm{H}_{2}$ receptor blockers 38.96. Conclusion: Our survey has shown that analgesics, $\mathrm{H}_{2}$ receptor blockers and tranquilizers constitute the most commonly used drugs in labour.
\end{abstract}

\begin{tabular}{ll}
\hline KARGER & (1) 1999 S. Karger AG, Basel \\
Fax +41613061234 & Ac11-7571/99/0082-0111\$17.50/0 \\
$\begin{array}{l}\text { E-Mail karger@karger.ch } \\
\text { www.karger.com }\end{array}$ & $\begin{array}{l}\text { Accessible online at: } \\
\text { http://BioMedNet.com/karger }\end{array}$
\end{tabular}

\section{Introduction}

Natural childbirth results in high morbidity and mortality, both of the mother and the fetus. Medical intervention has resulted in a dramatic drop in maternal and perinatal mortality. The administration of drugs during labour needs close scrutiny, since absorption, serum binding, distribution, and elimination of drugs are altered profoundly during pregnancy $[1,2]$.

In developed countries, advancing medical knowledge and the availability of improved technology have led to the development of safer methods for delivery and for monitoring the well-being of the fetus in utero. Advancement in technical skills like local anaesthesia has decreased the use of drugs like narcotic analgesics and sedatives. Furthermore, advances in laboratory methods for drug analysis have given greater insight into fetal and maternal pharmacokinetics.

\footnotetext{
Dr. Ma'asoumah Makhseed

Department of Obstetrics and Gynaecology, Faculty of Medicine PO Box 24923, Safat 13110 (Kuwait)

Tel. +965 5319601 (ext. 6475), Fax +965 5338906

E-Mailabrar@hsc.kuniv.edu.kw
} 


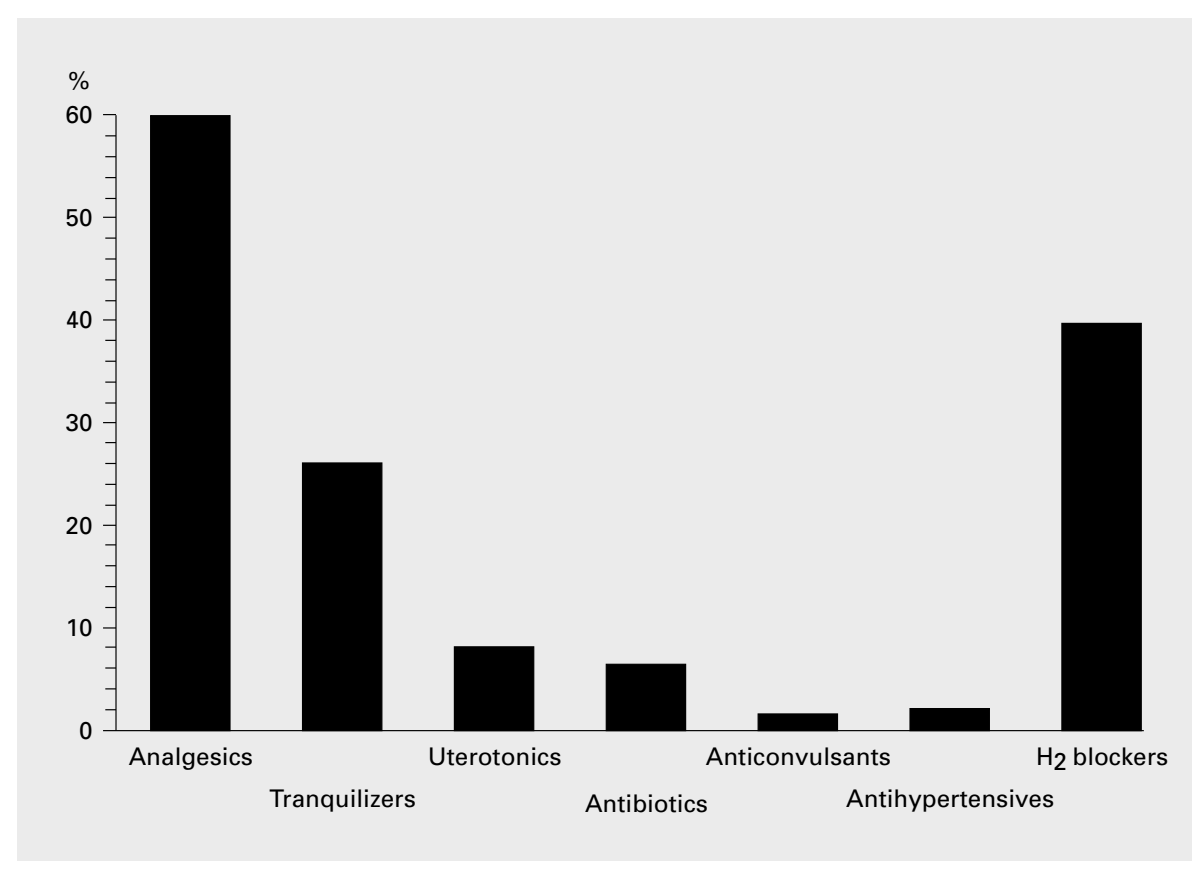

Fig. 1. Percentages of mothers using different classes of drugs in the labour room.

Previous studies on drug use in labour [35] have only focused on selected drugs or groups of drugs. In this pilot survey, we have attempted to study the trends of drugs used in labour in a developing country like Kuwait.

\section{Patients and Methods}

A drug survey of a total of 326 mothers was conducted in the labour room of the Maternity Hospital, Kuwait. This hospital, with 600 beds and an average of 15,000 deliveries per year, is the biggest government hospital in the Middle East. Data were collected from the prescription sheets and patient files by four doctors from the labour room based on a 4-day duty rotation schedule. Drugs in the present prescription and drugs used in labour for each mother were recorded. The drugs were classified as: analgesics (pethidine), tranquilizers/antiemetics (promethazine), uterotonics (oxytocin, prostaglandin), antibiotics (ampicillin, gentamicin, metronidazole), antihypertensives (labetalol), anticonvulsants (phenytoin), and $\mathrm{H}_{2}$ receptor blockers (ranitidine).

Mothers' ages ( $\leq 19,20-24,25-29,30-34$, and $\geq 35$ years) and nationality (Kuwaiti and non-Kuwaiti) were also recorded.

\section{Results}

Figure 1 shows the percentages of mothers using different classes of drugs: analgesics 59.5 , tranquilizers/antiemetics 25.5 , uterotonics 7.4, antibiotics/antimicrobials 5.5, anticonvulsants 0.9 , antihypertensives 1.5 , and $\mathrm{H}_{2}$ receptor blockers 38.96 .

Nationality and age of the mothers did not significantly affect the frequency of different classes of drugs used in the labour room (table 1). 
Table 1. Drugs used in labour by age and nationality of mothers

\begin{tabular}{|c|c|c|c|c|c|c|c|c|c|c|c|c|c|c|}
\hline \multirow[t]{3}{*}{ Drugs } & \multicolumn{10}{|c|}{ Age, years } & \multicolumn{4}{|c|}{ Nationality } \\
\hline & \multicolumn{2}{|c|}{$\begin{array}{l}\leq 19 \\
(n=16)\end{array}$} & \multicolumn{2}{|c|}{$\begin{array}{l}20-24 \\
(n=90)\end{array}$} & \multicolumn{2}{|c|}{$\begin{array}{l}25-29 \\
(n=100)\end{array}$} & \multicolumn{2}{|c|}{$\begin{array}{l}30-34 \\
(\mathrm{n}=82)\end{array}$} & \multicolumn{2}{|c|}{$\begin{array}{l}\geq 35 \\
(n=38)\end{array}$} & \multicolumn{2}{|c|}{$\begin{array}{l}\text { Kuwaiti } \\
(n=171)\end{array}$} & \multicolumn{2}{|c|}{$\begin{array}{l}\text { non-Kuwaiti } \\
(\mathrm{n}=150)\end{array}$} \\
\hline & $\mathrm{n}$ & $\%$ & $\mathrm{n}$ & $\%$ & $\mathrm{n}$ & $\%$ & $\mathrm{n}$ & $\%$ & $\mathrm{n}$ & $\%$ & $\mathrm{n}$ & $\%$ & $\mathrm{n}$ & $\%$ \\
\hline Analgesics & 9 & 56.3 & 54 & 60.0 & 60 & 60.0 & 49 & 59.5 & 22 & 57.9 & 103 & 60.2 & 91 & 60.7 \\
\hline Tranquilizers & 4 & 25.0 & 24 & 26.7 & 27 & 27.0 & 22 & 26.8 & 6 & 15.8 & 44 & 25.8 & 39 & 26.0 \\
\hline Uterotonics & 1 & 6.3 & 6 & 6.7 & 7 & 7.0 & 6 & 7.3 & 4 & 10.5 & 15 & 8.7 & 9 & 6.0 \\
\hline Antibiotics & 3 & 18.8 & 0 & & 8 & 8.0 & 7 & 8.5 & 0 & & 11 & 6.4 & 7 & 4.7 \\
\hline Anticonvulsants & 0 & & 1 & 1.1 & 1 & 1.0 & 1 & 1.2 & 0 & & 1 & 0.6 & 2 & 1.3 \\
\hline $\mathrm{H}_{2}$-receptor blockers & 6 & 37.5 & 41 & 45.5 & 36 & 36.0 & 33 & 40.2 & 11 & 28.9 & 72 & 42.1 & 55 & 36.7 \\
\hline Antihypertensives & 0 & & 1 & 1.1 & 2 & 2.0 & 2 & 2.4 & 0 & & 3 & 1.8 & 2 & 1.3 \\
\hline
\end{tabular}

\section{Discussion}

Labour pain causes a maternal stress response, with an increase in autonomic activity, release of catecholamines, and a decrease in placental perfusion, resulting in fetal acidosis. This stress may also cause maternal hyperventilation which leads to respiratory alkalosis, a compensatory metabolic acidosis, and thus fetal acidosis. In short, pain in labour is not good for the mother and the neonate; therefore, obstetric analgesia or anaesthesia should be considered. The safety of the mother and fetus must be a constant concern when considering analgesia or anaesthesia for labour and delivery. Virtually all drugs administered during labour pass through the placenta; thus, a balance must be sought between pain relief for the mother and safety for the fetus.

In the Maternity Hospital, a narcotic analgesic (pethidine) usually in combination with a tranquilizer (promethazine) is used for pain relief during labour. Promethazine potentiates the action of pethidine by sedating the patient and also antagonizes the emetic action of pethidine. Pethidine has achieved popularity over morphine because it is thought to produce less emesis and less pene- tration of the fetal blood-brain barrier [6]. Large and repeated doses may result in neonatal respiratory depression [7].

Regional (conduction) anaesthetic techniques like epidural anaesthesia for labour and pudendal block and spinal cord anaesthesia for second stage of labour are not performed in the Maternity Hospital. These techniques provide effective pain relief while avoiding the sedative and emetic effects of narcotic agents. The major disadvantages relate to the high cost and potential for such rare but serious maternal complications as cerebrospinal leak after an inadvertent spinal tap and total spinal paresis. In addition, by interfering with maternal expulsive efforts, there is an increased need for assisted delivery [8].

In studies where pain relief was assessed by means of a visual analogue score after pethidine administration, authors concluded that the pain reduction was in the order of $22 \%$ [9]. Eighty to $90 \%$ reduction has been reported after epidural block [10]. Maternal stress related hormones (endorphins, adrenocorticotrophic hormone, and cortisol) reach high levels during labour, but little or no reduction after the administration of pethidine. In contrast, concentrations of endorphins and cortisol are lowered rapidly by 
effective epidural anaesthesia [11]. In a study of three groups of women who received no medication, pethidine and epidural anaesthesia were included. No significant differences in the infants born to these mothers were found [12]. In a similar study performed by Brazelton in 1973, Apgar scores at 1 min were significantly greater in the no medication group, but there were no differences in the 5-min Apgar scores [13]. This phenomenon was attributable to the respiratory depression induced by the placentally transferred drug [14].
Oxytocin is used to induce or accelerate labour, and its use has saved many fetal lives and has reduced maternal morbidity and discomfort that are associated with prolonged labour. However, a number of studies have associated oxytocin administration with neonatal hyperbilirubinaemia $[15,16]$. Oxytocin should be administered under constant observation by experienced personnel under continuous electronic monitoring of fetal heart and uterine activities. Further studies involving a larger population survey are currently in progress.

\section{References}

1 Bogaert MC, Thiery M: Pharmacokinetics and pregnancy. Eur J Obstet Gynecol Reprod Biol 1983;16:229_ 235.

2 Nation RL: Drug kinetics in childbirth. Clin Pharmacokinet 1980;5: 340-364.

3 Ratten GJ: The use of drugs in pregnancy and labour. Aust Fam Physician 1978;9:1118-1126.

4 Dubowitz V: Neurological fragility in the newborn: Influence of medication in labour. Br J Anaesth 1975; 47:1005-1009.

5 American Academy of Pediatrics, Committee on Drugs: Effect of medication during labor and delivery on infant outcome. Pediatrics 1978;62: 402-403

6 Conner JT, Bellville JW, Wender R, Wapner S, Dorey FJ, Katz RL: Morphine and promethazine as intravenous premedicants. Anesth Analg 1977;56:801-807.

7 Kuhnert BR, Kuhnert PM, Tu ASL, Lin DC: Meperidine and normeperidine levels following meperidine administration during labor. II Fetus and neonate. Am J Obstet Gynecol 1979;133:909-914.
8 Hoult IJ, MacLennan AH, Carrie LE: Lumbar epidural analgesia in labour: Relation to fetal malposition and instrumental delivery. Br Med J 1977;i:14-16.

9 Vella L, Francis D, Houlton P, Reynolds F: Comparison of antiemetics, metoclopramide and promethazine in labour. Br Med J 1985;290:11731175.

10 Morgan B, Bulpitt CJ, Clifton P, Lewis PJ: Effectiveness of pain relief in labour: Survey of 1,000 mothers. $\mathrm{Br}$ Med J 1982;285:689-690.

11 Brinsmead MW, Smith R, Singh B, Lewin T, Owens P: Peripartum concentrations of beta endorphin and cortisol and maternal mood states. Aust NZ J Obstet Gynaecol 1985; 25:194-197.

12 Lieberman BA, Rosenblatt DB, Belsey E, Packer M, Redshaw M, Mills M, Caldwell J, Notarianni L, Smith RL, Williams M, Beard RW: The effects of maternally administered pethidine or epidural bupivacaine on the fetus and newborn. Br J Obstet Gynaecol 1979;86:598-606.
13 Brazelton TB: Neonatal behavioral assessment scale. London: Spastics International Medical Publications with Heinemann Medical Books, 1973. (clinics in developmental medicine no. 50)

14 Nandakumaran M, Olive G: Placental transfer of drugs: A minireview; in Roy Chowdhury NN, Roy Chowdhury J (eds): Recent Trends in Perinatology. Calcutta, Nachiketa, 1983, pp 141-178.

15 Calder AA, Moar VA, Ounsted MK, Turnbull AC: Increased bilirubin levels in neonates after induction of labour by intravenous prostaglandin $\mathrm{E}_{2}$ or oxytocin. Lancet 1974;ii: 1339-1345.

16 Sivasuriya M, Tan KL, Salmon YM, Karim SSM: Neonatal serum bilirubin levels in spontaneous and induced labour. Br J Obstet Gynaecol 1978;85:619-623. 